\title{
ОСНОВОПОЛОЖНІ ЗАСАДИ ДЕРЖАВНОГО УПРАВЛІННЯ ВИБОРЧИМ ПРОЦЕСОМ В УКРАЇНІ: ТЕОРЕТИКО-МЕТОДОЛОГІЧНИЙ ОГЛЯД ВІТЧИЗНЯНИХ ДОСЛІДЖЕНЬ
}

\author{
КУЗИК Петро Миколайович - здобувач кафедри публічного адміністрування \\ ПрАТ ВНЗ «Міжрегіональна Академія управління персоналом" \\ DOI 10.32782/LAW.UA.2021.4.5
}

Статья посвящена обобщению основополагающих принициов государственного управления избирательньлм процессом в Украине и их отражения в отечественной научной среде.

В ходе исследования проанализированъ нормы действующего законодательства и теоретические наработки отечественньгх и зарубежных исследователей, посвященных как непосредственно государственному управлению избирательньлм процессом, его правовому регулированию, так и особенностям соблюдения безопасности избирательного процесса.

Вияснено, что украинские ученъие рассматривали такие аспекть исследуемой проблематики, как: теоретико-методологические основъ государственного управления избирательньмм процессом в Украине; модернизачия системъ государственного управления в контексте развития гражданского общества в Украине; теоретико-методологические основы организачии местного самоуправления в Украине в контексте повышения эббективности его деятельности; механизмь реализации коммуникативного взаимодействия в сбере публичного управления; государственная политика в области средств массовой коммуникащии в условиях общественнъих трансбормаций в Украине; государственная инфбормационная политика в современном политическом пространстве.

Отдельное внимание уделено вопросам организачии и обеспечения безопасности въгоров в Украине, в частности: проблематике организаиии форсайта безопасности избирательного процесса в контексте государственного управле- ния; проблематике безопасности въгоров в условиях необъявленной, гибридной войнъ и пандемии COVID-19; проблематике обеспечения права голосовать на местнъх въгборах внутриперемещенньлх лии; проблематике безопасности персональньих данньх избирателей, зашить инбормачионно-аналитических систем от кибератак; проблематике антикризисного управления избирательньм процессом в Украине.

Ключевъле слова: въгорь, избирательньий прочесс, государственное управление, государственное управление избирательньлм процессом, правовое регулирование, теоретико-методологический обзор, безопасность избирательного проиесса, Форсайт безопасности.

Обгрунтування актуальності обраної теми дослідження

Европейський вибір України обумовлює необхідність модернізації державного управління демократичним розвитком держави, у тому числі - виборчим процесом. Верховенство права, забезпечення прав та свобод людини й громадянина, здійснення легітимних, вільних, чесних виборів $\epsilon$ не просто європейськими орієнтирами для України, але й неодмінною умовою ії міжнародного визнання як демократичної і правової держави.

Важливість дослідження теоретичних підходів щодо державного управління виборчим процесом у нашій державі загострюється 3 огляду на необхідність формування дієвих моделей прогнозування загроз проведенню чесних виборів, що набуває особливого значення 
в умовах поширення кіберзагроз, порушення територіальної цілісності України, поширення заходів, спрямованих на протидію пандемiї COVID-19.

Усе це обумовлює високу актуальність дослідження теоретичних підходів щодо основоположних засад державного управління виборчим процесом в Україні.

\section{Аналіз попередніх досліджень і публікацій}

Основоположні засади державного управління та правового регулювання в контексті національної та інформаційної безпеки вивчали численні вітчизняні та зарубіжні науковці, зокрема: С.С. Бучик, O.I. Варченко, В.І. Григор'єв, Ю.С. Довгаль, Я.М. Жарков, I.Ф. Корж, В.В. Кульчицький, С.О. Аисенко, О.В. Литвиненко, А.Р. Наливайко, А.Ю. Нашинець-Наумова, В.Г. Пилипчук, А.М. Подоляка, Є.Д. Скулиш, В.Ю. Степанов В.С. Цимбалюк, Р.Ф. Черниш, А.В. Чунарьова, О.В. Шевякова, О.К.Юдін та ін. Проблеми довіри до органів публічної влади в контексті демократичного державотворення з'ясовували О.П. Айвазовська, О.О. Бабінова, М.Й. Братковський, А.М. Костецька, О.Г. Кучабський, І.П. Аопушинський, О.Є. Макух, А.Б. Міщенко, С.С. Погорєлий та ін.

При цьому узагальнення їх підходів щодо трактування ними засад державного управління виборчим процесом в Україні у вітчизняній науці зроблено не було, що й обумовлює актуальність нашого дослідження.

Метою дослідження виступає систематизація вітчизняних наукових напрацювань, які присвячені теоретико-концептуальному обгрунтуванню проблематики державного управління виборчим процесом.

\section{Основний зміст дослідження}

Наразі у вітчизняній науці дедалі більшого поширення набуває комплексний підхід до вивчення суспільних відносин. У цьому контексті доречним видається систематизація теоретичних поглядів на державне управління виборчим процесом. У найбільш узагальненому вигляді можна викоремити такі складові цього підходу, як теоретико-концептуальні засади державного управління виборчим про- цесом та науково-прикладні засади державного управління виборчим процесом.

Крім того, окремої уваги заслуговують сутність поняття «виборчий процес» у теоретиконаукових підходах, законодавчі засади виборчого процесу та безпека виборчого процесу.

Теоретико-концептуальне обгрунтування проблематики державного управління виборчим процесом було здійснено, зокрема в наступних роботах:

- проблематика форсайту безпеки в контексті безпекознавства в цілому, права та державного управління - аналітико-прогностичні дослідження автора [1]; С.О. Аисенка [2], С.Ф.Серьогіної, І.О.Баришева [3]; Н.Н.Талеба [4];

- державне управління виборчим процесом в Україні: теоретико-методологічні засади, у якому А.П. Савков зазначав, що теоретичним підгрунтям для державного управління виборчим процесом (ВП) з метою задоволення суспільних потреб, у тому числі потреби безпеки, може бути концепція «політичних мереж», що обумовлює необхідність неухильного виконання державою функції суспільної координації. Політична мережа розглядається як система державних та недержавних утворень у певній сфері, що взаємодіють між собою на основі інституційної, ресурсної та інших видів залежності $з$ метою досягнення загальної згоди щодо політичних питань, які всіх цікавлять та турбують, з використанням формальних та неформальних норм.

Основою цієї концепції $\varepsilon$ обов'язкове існування взаємної довіри та взаємних зобов'язань учасників виборчого процесу. Акцентовано, що застосування цієї концепції, по-перше, змусить усіх, хто іде на вибори, нести перед електоратом відповідальність за всі передвиборчі політичні обіцянки-тексти; по-друге, наповнить реальним змістом громадський контроль за перебігом виборів; потретє, перетворить органи державної влади із своєрідного «розпорядника, адміністратора» на рівноправного учасника, зацікавленого в досягненні спільного інтересу, узгодженого 3 усіма суб'єктами виборчого процесу, а саме: забезпеченні об'єктивності та неупередженості електорального процесу [5, с. 11-12];

- теоретико-методологічні засади розвитку державного управління виборчим процесом в 


\section{Теорія, історія держави і права, конституційне право}

Україні (на основі досвіду країн СС) - дисертаційне дослідження В. Ю. Когутюк [6];

- проблематика модернізації державного управління на основі концептуального моделювання «нового державного менеджменту», концепції «суспільно-політичних мереж», концепції «governance» (врядування), які визначають концептуальне бачення політико-адміністративної реформи в Україні, її складові: досягнення згоди більшості політичних і громадських сил щодо стратегії, цілей і змісту реформи; побудова демократичної моделі політичної системи; створення структур для координації і узгодження дій усіх акторів реформаторського поля; політична воля і відповідальність вищих посадових осіб держави; повернення до мажоритарної виборчої системи на місцевих виборах та до змішаної - на парламентських; створення інститутів багатостороннього політико-громадського діалогу - дисертаційне дослідження О.Г.Пухкал [7, с. 9];

Науково-прикладні засади вирішення проблем державного управління виборчим процесом в Україні теж не лишилися поза увагою науковців. Серед іншого, вони з'ясовувалися в межах ряду дисертаційних досліджень:

- теоретико-методологічні засади організації місцевого самоврядування (ОМС) в Україні - дисертаційне дослідження П.В.Ворони, у якому представлено вирішення проблеми підвищення ефективності організації місцевого самоврядування на основі запровадження двотурової мажоритарної системи виборів голів територіальних громад; впровадження кваліфікаційних вимог у процесі балотування на посаду голови громади; призначення позачергових виборів на основі рішень адміністративних судів. Проаналізовано соціально-політичне явище «дуалізм виборчих уподобань» як неоднозначність ідеологічного волевиявлення виборців під час голосування до парламенту й рад різніх рівнів [8, с.24-25];

- механізми реалізації комунікативної взаємодії у сфері публічного управління - дисертаційне дослідження О.А.Рачинської, у якому розглянуті проблеми загального виборчого права та безпеки державних службовців (психологічної безпеки), державної безпеки, проблеми небезпеки для інститутів громадського суспільства, проблеми інформаційної безпеки суспільства та громадянина, невирішеність проблем фінансової незалежності медіа у період виборчих компаній, коли суспільство потребує об'єктивного політичного інформування задля здійснення вільного волевиявлення щодо політичного майбутнього держави [9];

- державна політика у сфері засобів масової комунікації в умовах суспільних трансформацій в Україні - дисертаційне дослідження Ю.В. Нестеряк, що включало проблематику механізмів державного регулювання та саморегулювання засобів масової комунікації під час виборчих кампаній, зокрема розгляд європейських стандартів висвітлення виборів у засобах масової комунікації на основі рекомендації Комітету Міністрів Ради Европи; аналіз висвітлення виборчих компаній в Україні на основі досліджень вітчизняних науковців, міжнародних спостерігачів та державних регуляторних органів; представлення методології та результатів медіамоніторингу щодо забезпечення права на об'єктивну і збалансовану інформацію під час парламентських виборів в Україні; вдосконалення державного регулювання та саморегулювання засобів масової комунікації під час виборчих кампаній в Україні; визначення напрямів вдосконалення формування та реалізації державної політики у сфері інформаційної безпеки України [10, C.3-4];

- державна інформаційна політика у сучасному політичному просторі - дослідження В.Ю.Степанова, що акцентує увагу на проблематиці критеріїв ІБ держави, забезпеченні безпеки національного інформаційного простору, захисту персональних даних, ефективної комунікації з виборцями як «керованим» співтовариством, що припускає формування або коректування громадської думки [11, с. 77];

- особливості реалізації органами місцевого самоврядування державної політики в умовах трансформації українського суспільства - дисертаційне дослідження B.I.Шария, у якому представлено проблематику упровадження європейських принципів реалізації державної політики в діяльність органів місцевого самоврядування України, а саме реалізація передвиборчої програми, політичного курсу, схваленого більшістю виборців; впровадження транзитивної моделі реалізації політики ОМС в Україні [12, с.13]. 
Не залишилася осторонь уваги дослідників і проблема сутності поняття «виборчий процес». Їй присвячено праці таких учених як: А.С. Бандурка [13], Ю.Г. Барабаш [14], Ф.В.Веніславський [15], В.П.Колісник [16], А.М. Костецька [17], В.В.Молдован, В.Ф. Мелещенко [18] та інші.

Питанням виборчого права, стандартів, принципів,стабільності виборів та виборчого процесу та їх адаптації до умов України присвячено дослідження таких учених як Н.В. Богашева, Ю.Б. Ключковський [19; 20], М.А. Бучин [21], Р.П. Князевич [22], В.Ф. Мелещенко, В.В.Молдован [18], Ю.В. Нестеряк [10], А.П. Савков [5]. Натомість більш детально проблеми вдосконалення виборчої системи досліджували Н.В. Богашева, Ю.Б. Ключковський, А.В.Колісецька [23], В.В. Молдован, В.Ф. Мелещенко [18], О.Г. Пухкал [7], А.П. Савков [5] та ін.

Під час вивчення деяких аспектів еволюції виборчого законодавства України протягом періоду 1986-2006 років дослідники Н.В. Богашева, Ю.Б. Ключковський, А.В. Колісецька розглядали загальнонародні вибори актом народного волевиявлення, завдяки якому політична воля нації безпосередньо втілюється у владні політичні структури, легітимізує їх, стає державною волею [23]. Однак у цілому, для сьогодення $є$ характерною неоднозначність розуміння поняття «виборчий процес» у наукових підходах. Його розглядають у таких трактуваннях як: специфічна діяльність уповноважених органів і громадян держави, яка регулюється законодавством та спрямована на формування конституційного якісного і кількісного складу органів державної влади та органів місцевого самоврядування [24]; процес, що грунтується на нормативно-правових актах і має ознаки правової врегульованості та закритості [25, с. 51]; сукупність послідовних, логічно обумовлених стадій (етапів) здійснення виборчих процедур, спрямованих на формування органів державної влади та органів місцевого самоврядування [14, с. 115]; складна структура технологій забезпечення і захисту активного і пасивного виборчого права громадян України на основі послідовного впровадження комплексу виборчих дій та процедур [26]; встановлена законодавством процедура, порядок організації і проведення виборів, один із елементів виборчої системи [18].

Відповідно до чинного законодавства, «виборчий процес» вважається процесом, що повинен реалізуватися на засадах: 1) гарантії реалізації виборчих прав громадян;2) дотримання основних принципів виборчого права; 3) законності та заборони незаконного втручання будь-кого у цей процес; 4) політичного плюралізму та багатопартійності;5) публічності та відкритості виборчого процесу; 6) свободи передвиборної агітації, рівних умов доступу кандидатів на пост Президента України до засобів масової інформації; 7) неупередженості органів виконавчої влади, органів влади Автономної Республіки Крим, органів місцевого самоврядування, підприємств, закладів, установ і організацій, їх керівників, інших посадових і службових осіб до кандидатів на пост Президента України, партій [27].

Вибори можна вважати найбільш поширеною формою прямого народовладдя,яка застосовується у більшості країн світу; це сучасна цивілізована правова форма оновлення влади, приведення ії структур та діяльності у відповідність до потреб життя [28]. Як зазначає А.М.Костецька, вибори лише за певних умов $\epsilon$ елементом демократії та сприяють ії розвиткові, а також є формою прямої влади народу в демократичній державі. Щоб стати атрибутом демократичного політичного режиму, вибори повинні проводитися у відповідності 3 міжнародними нормами і стандартами, які сьогодні є пріоритетними по відношенню до внутрішнього законодавства України [29].

Європейська комісія «За демократію через право» (Венеціанська комісія) у своїх рекомендаціях зазначає, що вибори, які відповідають спільним для європейського доробку засадам, на які спирається справді демократичне суспільство, мають проводитися з дотриманням таких основних норм: виборче право має бути загальним, рівним, вільним і прямим при таємному голосуванні. Крім того, вибори мають проводитися регулярно. Також звертається увага на те, що найбільш принципові норми виборчого законодавства, зокрема ті, що регулюють саму виборчу систему, склад виборчих комісій і визначення меж виборчих округів, доцільно закріплювати в конституції або в акті, що має вищий статус, аніж звичайний 


\section{Теорія, історія держави і права, конституційне право}

закон (пункт 66 Пояснювальної доповіді до зазначених вище Керівних принципів щодо виборів) [30],

Державне управління виборчим процесом базується на засадах національного виборчого законодавства та державно-управлінської практики і орієнтується на міжнародні стандарти у цій сфері. Рекомендується при визначенні поняття «виборчий процес» у контексті державного управління виходити 3 того, що це послідовність подій, сукупність різних форм взаємодії та послідовних дій з висунення, агітації та голосування за суб’єктів політичної і державної влади, самоврядування, персональний та структурний склад яких формується вираженням волі тієї частини населення, яка за законодавством вважається достатньою для визнання результатів виборів легітимними. Тобто це процес, у результаті якого здійснюється відновлення політичних та державних інститутів, що забезпечує формування владних структур у ході реалізації виборчих демократичних процедур.

Ефективність або результативність влади полягає в результатах реалізації всіх задумів, платформ, програм, іï здатності ефективно управляти всіма сферами суспільного життя, досягати політичної мети оптимальними засобами. Одразу виникає проблема встановлення універсального критерію, за яким можна об'єктивно визначити ефективність політичної влади.

Окремої уваги заслуговує проблематика безпеки виборів та ії відображення у наукових та аналітичних дослідженнях, зокрема: у науковій праці М.А.Бучина поставлена проблема безпеки виборів в Україні у 2014 році в умовах неоголошеної, гібридної війни, що поставило комплекс безпекових загроз [31]; у дисертаційному дослідженні В.Ю.Когутюка встановлено взаємозв'язок і взаємозалежність виборчого процесу та політичної, соціальної безпекової систем і системи державного управління, а також виявлено, що проблема забезпечення безпеки виборчого процесу є процесуальною гарантією для реалізації основоположних принципів у європейській практиці [6, с. 6, 9]; у дослідженнях, які присвячені проблематиці організації форсайту безпеки, зокрема в роботах С. О. Аисенка [2], Н. Н. Талеба [4]; форсайту безпеки виборчого процесу в контексті державного управління (дослідження автора) [1]; у дисертаційному дослідженні Л.М.Костецької поставлена проблема антикризового управління національним виборчим процесом 3 метою мінімізації можливих кризових ситуацій при управлінні виборчим процесом в Україні; обгрунтовано основні чинники кризи виборчого процесу і тенденції запровадження антикризового управління виборчим процесом у країні; розроблено модель антикризового управління виборчим процессом [17]; у публікаціях I.В.Ткаченко [32], Н.Бутирської [33], Всеукраїнської громадської організації «Комітет виборців України» [34] де було доволі детально розглянута проблематика безпеки проведення виборів в умовах пандемії тощо.

\section{Висновки і перспективи подалыших досліджень}

Проведений аналіз теоретичного підгрунтя проблематики державного управління виборчим процесом в Україні дозволив систематизувати наукові дослідження, які присвячені теоретико-концептуальному обгрунтуванню проблематики державного управління виборчим процесом.

Виявлено, що українськими вченими розглядалися наступні аспекти цієї проблематики: форсайт безпеки в контексті безпекознавства, права та державного управління; теоретикометодологічні засади державного управління виборчим процесом в Україні; перспективні методи організації безпеки виборчого процесу; модернізація системи державного управління в контексті розвитку громадянського суспільства в Україні; теоретико-методологічні засади організації місцевого самоврядування в Україні в контексті підвищення ефективності їх діяльності; механізми реалізації комунікативної взаємодії у сфері публічного управління; державна політика у сфері засобів масової комунікації в умовах суспільних трансформацій в Україні; державна інформаційна політика у сучасному політичному просторі; особливості реалізації органами місцевого самоврядування державної політики в умовах трансформації українського суспільства; детермінанти ефективності політичної влади.

Констатовано, що для сьогодення є характерною неоднозначність розуміння понят- 
тя «виборчий процес»у наукових підходах. 3'ясовано, що сутністю поняття «вибори» $\epsilon$ розуміння їх як найбільш поширеної форми прямого народовладдя в демократичній державі, сучасної цивілізованої правової форми оновлення влади, приведення іï структур та діяльності у відповідність до потреб життя.

Слід відзначити, що питання організації та забезпечення безпеки виборів в Україні з'ясовувалися в наукових та аналітичних дослідженнях як багатогранна проблема: проблеми організації форсайту безпеки виборчого процесу в контексті державного управління; проблеми безпеки виборів в умовах неоголошеної, гібридної війни та пандемії, що поставило комплекс безпекових загроз; проблеми забезпечення права голосувати на місцевих виборах внутрішньо переміщених осіб в Україні; проблеми безпеки персональних даних виборців, захисту інформаційно-аналітичних систем від кібератак; проблеми антикризового управління виборчим процесом в Україні для мінімізації кризових ситуацій.

\section{Аiтература}

1. Кузик П.М. Перспективні .методи організації безпеки виборчого процесу: форсайт безпеки у контексті державного управління. Наукові перспективи. Вип. №4(10). 2021. С.50-60.

2. Аисенко С. О. Майбутній погляд на організацію безпеки: форсайт безпеки і як ним користуватися. Наше право, 2020. № 3. с. 78-84.

3. Серегина С. Ф., Барышев И. А. Закономерно ли появление форсайта? // Форсайт. 2008. № 2(6). T. 2 С. 4-12.

4. Талеб Н. Чорний лебідь: Про (не)ймовірне в реальному житті. Київ: Наш Формат, 2017. 392 c.

5. Савков А. П. Державне управління виборчим процесом в Україні: теоретико-методологічні засади: автореф. дис. ... д-ра наук 3 держ. упр. : 25.00.01 / А. П. Савков ; ВР України, Ін-т законодавства. К., 2010. 36 с. укр.

6. Когутюк В.Ю. Теоретико-методологічні засади розвитку державного управління виборчим процесом в Україні (на основі досвіду країн (GC). : автореф. дис. ... канд. наук з держ. упр.: 25.00.01/ Наи. акад. держ. упр. при Президентові Украӥни. Київ, 2017. 20 с.

7.Пухкал О.Г. Модернізація системи державного управління в контексті розвитку гро- мадянського суспільства в Україні автореф. дис. ... д-ра наук з держ. упр.: 25.00.01 / Наu. акад. держ. упр. при Президентові Украӥни. Київ, 2011. 40 c.

8. Ворона П.В. Теоретико-методологічні засади організації місцевого самоврядування в Україні : автореф. дис. ... д-ра наук з держ. упр. : 25.00 .04 «Міси. Самоврядування». Київ, 2013. 38 c.

9. Рачинська О. А. Механізми реалізації комунікативної взаємодії усфері публічного управління: автореф. дис. ... канд. наук 3 держ. упр. : 25.00.02. Інститут підготовки кадрів державної служби зайнятості Украӥни. Київ, 2019. 20 c.

10. Нестеряк Ю. В. Державна політика у сфері засобів масової комунікації в умовах суспільних трансформацій в Україні : дис. ... д-ра наук з держ. упр. : 25.00.01 / Ю. В. Нестеряк; Наи. акад. держ. упр. при Президентові Украйни. Київ, 2016. 436 с.

11. Степанов В. Ю. Державна інформаційна політика в сучасному політичному просторі / В. Ю. Степанов // Інвестицй: практика та досвід. 2011. № 3. С. 76-78.

12. Шарий B.I. Особливості реалізації органами місцевого самоврядування державної політики в умовах трансформації українського суспільства : автореф. дис. ... д-ра наук 3 держ. упр. : 25.00.04 «Міси. Самоврядування». Київ, 2013. 39 с.

13. Бандурка А.С. Конституційні засади виборчого процесу в Україні. Європейські перспективи. 2015. Вип. 7. С. 28-37.

14. Конституційне право України: Підруч. для студ. вищ. навч. закл. / За ред. В. П. Колісника та Ю. Г. Барабаша. Харків: Право, 2008. $416 \mathrm{c}$.

15. Виборчі спори: експертна оцінка якості судових рішень (місцеві вибори 2015 року): аналіт. звіт / Т. Калмиков та ін.; USAID від америк. народу, Проект «Справедиве правосуддя», Iн-т приклад. гуманітар. дослідж. Харків: Ін-т приклад. гуманітар. дослідж., 2016. 64 с.

16. Науково-практичний коментар до статті 23 Закону України «Про вибори народних депутатів України». URL: https://ips. ligazakon.net/document/KZ000023. (дата звернення 16.05.2021).

17. Костецька А.М. Особливості антикризового управління виборчим процесом 


\section{Теорія, історія держави і права, конституційне право}

в Україні. Дисертація на здобуття наукового ступеня кандидата наук з державного управління за спеціальністю 25.00.01 - «Теорія та історія державного управління» - Національна академія державного управління при Президентові Украӥни, Київ, 2019. 264 с.

18. Молдован В. В. Конституційне право: опорні конспекти: Навч. посібник для студентів юрид. вузів та фак-тів / В. В. Молдован,В. Ф. Мелещенко. Київ. Юмана, 1996. - 272 с.

19. Богашева Н.В. Законодавче регулювання виборів в Україні: проблеми стабільності. Наукові записки Інституту законодавства Верховної Ради Украӥни. 2014. № 2. С. 32-38.

20. Богашева Н.В., Ключковський Ю.Б. Міжнародні стандарти демократичних виборів та законодавство про вибори народних депутатів України. Вибори та демократія. 2012. № 2(32). С. 29-50.

21. Бучин М.А. Еволюція демократичних принципів виборів: дис. ... д-ра. наук з держ. упр: 23.00.02/ Нач. ун.-m «Һввівсъка політехніка», 2016. $488 \mathrm{c}$.

22. Князевич Р.П. Конституційно-правові засади виборів Президента України: проблеми теорії і практики. автореф. дис. ... канд. юрид. наук: 12.00.02 / Наи. ун.-m «Одесъка юридична академія». Одеса, 2002. 18 с. URL: http://dspace. onua.edu.ua/bitstream/handle/11300/1341/\%d0\% 9a\%d0\%bd\%d1\%8f\%d0\%b7\%d0\%b5\%d0\%b2\%d 0\%b8\%d1\%87.pdf? sequence $=1$ \&isAllowed $=y$

23. Богашева Н.В., Ключковський Ю.Б., Колісецька А.В. Дослідження деяких аспектів еволюції виборчого законодавства України (19892006 роки). Київ: ПЦ «Фоліант». 2006. 146 с.

24. Ставнійчук M.I. Законодавство про вибори народних депутатів України: актуальні проблеми теорії і практики. Київ: Факт, 2001. c. 156 .

25. Наход М. А. Категорії «вибори» та «виборчий процес» в сучасній науці державне управління / М. А. Наход // Ребормування системи державного управління та державної служби: теорія $і$ практика: матеріали наук.-практ. конф. за міжнар. участю (8 квітн. 2011 р.): у ч.2. Ч. 1 / за наук. ред. чл.-кор. НАН України В. С. Загорського, доц. А. В. Аіпінцева. Аьвів: АРІДУ НАДУ, 2011. - С. 49-53.

26. Яворський В. Д. Сучасний виборчий процес в Україні: політико- правовий аспект / В. Д. Яворський // Вибори Президента Украйни-
99: проблеми теорї і практики [Текст]: зб. матеріалів міжнарод. наук.- практ. конф. (доп., виступи, рек.) / Центральна виборча комісія; голов. ред. М. М. Рябець. 2000. 283 с.: іл.). Київ. ЦВК, 2000. С. 84-86.

27. Виборчий кодекс України: Закон України № 396-IX від 19 грудня 2019 р. URL : https://zakon.rada.gov.ua/laws/show/39620\#Text

28. Стешенко Т.В. Актуальні питання виборчого процесу. Державне будівництво та місиеве самоврядування. 2013. Вип.25. С.103.

29. Костецька $\mathcal{\lambda}$. Проблеми регулювання виборчого процесу в Україні. Наукові записки Інституту законодавства Верховної Ради Украйни. Вип.1. 2017. С.154- 160.

30. Європейський демократичний доробок у галузі виборчого права: Матеріали Венеціанської Комісії, Парламентської Асамблеї, Комітету Міністрів, Конгресу місцевих і регіональних влад Ради Европи: пер. $з$ англ. / за ред. Ю.Ключковського. Вид. 2-е, випр. і доповн. Київ, 2009. 500 с.

31. Бучин М. Проблема безпеки виборів 2014 року в Україні. Політичні науки. 2015. Вип.1 №1. С.1-5.

32. Ткаченко I. Европейські вибори під час пандемії: до чого варто готуватися Україні восени 2020 року. URL: https:/www.eurointegration. com.ua/articles/2020/04/7/7108431/

33. Бутирська Н. Пандемія пандемією, а вибори - за розкладом. URL : https://dt.ua/international/pandemiyapandemiyeyu-a-vibori-za-rozkladom-344972. html?fbclid=IwAR14Urk dCbXJL-lMCPRa4d OGvS3a8NUD3FFbkJ1RT5VCmhdgwkAR4KJs $\underline{\mathrm{tU}}$

34. Вибори в умовах пандемії: міжнародний досвід і рекомендації для України: посібник. 45 с. URL : https://www.kas.de/docum ents/270026/0/\%D0\%92\%D0\%B8\%D0\%B1\%D 0\%BE\%D1\%80\%D0\%B8-\%D0\%B2-\%D1\%83\% D0\%BC\%D0\%BE\%D0\%B2\%D0\%B0\%D1\%85$\% \mathrm{D} 0 \% \mathrm{BF} \% \mathrm{D} 0 \% \mathrm{~B} 0 \% \mathrm{D} 0 \% \mathrm{BD} \% \mathrm{D} 0 \% \mathrm{~B} 4 \% \mathrm{D} 0 \%$ B5\%D0\%BC\%D1\%96\%D1\%97\%D0\%BC\%D1 $\% 96 \% \mathrm{D} 0 \% \mathrm{~B} 6 \% \mathrm{D} 0 \% \mathrm{BD} \% \mathrm{D} 0 \% \overline{\mathrm{B}} 0 \% \mathrm{D} 1 \% 80 \% \mathrm{D}$ 0\%BE\% D0\%B $4 \% \mathrm{D} 0 \% \mathrm{BD} \% \mathrm{D} 0 \% \mathrm{~B} 8 \% \mathrm{D} 0 \% \mathrm{~B} 9-$ $\% \mathrm{D} 0 \% \mathrm{~B} 4 \% \mathrm{D} 0 \% \mathrm{BE} \% \mathrm{D} 1 \% 81 \% \mathrm{D} 0 \% \mathrm{~B} 2 \% \mathrm{D} 1$ $\% 96 \% \mathrm{D} 0 \% \mathrm{~B} 4-\% \mathrm{D} 1 \% 96-\% \mathrm{D} 1 \% 80 \% \mathrm{D} 0 \% \mathrm{~B}$ $5 \% \mathrm{D} 0 \% \mathrm{BA} \% \mathrm{D} 0 \% \mathrm{BE} \% \mathrm{D} 0 \% \mathrm{BC} \% \mathrm{D} 0 \% \mathrm{~B} 5 \%$ D0\%B D \% D0\%B 4\% D0\% B 0\% D 1\%86\% D 1\% 
Кузик П.М. - Основоположні засади державного управління виборчим процесом...

\section{АНОТАЦІЯ}

Статтю присвячено узагальненню основоположних засад державного управління вибориим процесом в Україні та їх відображення у вітиизняному науковому середовищі.

В ході дослідження проаналізовано норми чинного законодавства $i$ теоретичні напрацюовання вітчизняних $i$ зарубіжних дослідників, присвячених як безпосереднъо державному управлінню вибориим процесом, $і$ його правовому регулюванню, так $і$ особливостям дотримання безпеки виборчого процесу.

З’ясовано, що українсъкими вченими розглядалися такі аспекти досліджуваної проблематики як: теоретико-методологічні засади державного управління виборчим процесом в Україні; модернізачія системи державного управління в контексті розвитку громадянсъкого суспільства в Україні; теоретико-методологічні засади організащиї місцевого самоврядування в Україні в контексті підвищення ебективності його діяльності; механізми реалізачій комунікативної взаємодї у сбері публічного управління; державна політика у сфері засобів масової комунікаиій в умовах суспільних трансформацій в Україні; державна інформачійна політика у сучасному політичному просторі.

Окрему увагу присвячено питанням організачиї та забезпечення безпеки виборів в Україні, зокрема: проблематиці організаиї форсайту безпеки виборчого процесу в контексті державного управління; проблематиці безпеки виборів в умовах неоголошеної, гібридної війни та пандемій COVID-19; проблематииі забезпечення права голосувати на місцевих виборах внутрішнъо переміщених осіб; проблематиці безпеки персональних даних вибориів, захисту інформаційно-аналітичних систем від кібератак; проблематиці антикризового управління вибориим процесом в Україні.

Ключові слова: вибори, виборчий прочес, державне управління, державне управління вибориим прочесом, правове регулювання, теоретико-методологічний огляд, безпека виборчого процесу, борсайт безпеки.

96\% D 1\%97-\% D 0\% B 4\% D 0\% B B \% D $1 \% 8 \mathrm{~F}-$ $\% \mathrm{D} 0 \% \mathrm{~A} 3 \% \mathrm{D} 0 \% \mathrm{BA} \% \mathrm{D} 1 \% 80 \% \mathrm{D} 0 \% \mathrm{~B} 0 \% \mathrm{D} 1 \% 97 \%$

\section{SUMMARY}

The article is devoted to the generalization of the fundamental principles of public administration of the electoral process in Ukraine and their reflection in the domestic scientific community.

In the course of the study, the norms of the current legislation and theoretical developments of domestic and foreign researchers were analyzed, devoted to both the direct state management of the electoral process, its legal regulation, and the peculiarities of observing the security of the electoral process.

It was found that Ukrainian scientists considered such aspects of the studied problem as: theoretical and methodological foundations of state management of the electoral process in Ukraine; modernization of the public administration system in the context of the development of civil society in Ukraine; theoretical and methodological foundations of the organization of local self-government in Ukraine in the context of increasing the efficiency of its activities; mechanisms for the implementation of communicative interaction in the field of public administration; state policy in the field of mass communication in the context of social transformations in Ukraine; state information policy in the modern political space.

Special attention is paid to the issues of organizing and ensuring the security of elections in Ukraine, in particular: the problems of organizing the foresight of the security of the electoral process in the context of public administration; election security issues in the context of an undeclared, hybrid war and the COVID-19 pandemic; problems of ensuring the right to vote in local elections for internally displaced persons; issues of security of personal data of voters, protection of information and analytical systems from cyber attacks; anti-crisis management of the electoral process in Ukraine.

Key words: elections, electoral process, public administration, public administration of the electoral process, legal regulation, theoretical and methodological review, security of the electoral process, security foresight.

D0\%BD\%D0\%B8.pdf/ffba9f40-d846-01b0-5a0c$\underline{707 \mathrm{f} 77 \mathrm{e} 7 \mathrm{e} 301 \text { ?version }=1.0 \& \mathrm{t}=1592900587954}$ 